\title{
Feasibility and effectiveness of afatinib for poor performance status patients with EGFR-mutation-positive non-small-cell lung cancer: a retrospective cohort study
}

Chiao-En Wu ${ }^{1+}$, Ching-Fu Chang ${ }^{1 \dagger}$, Chen-Yang Huang ${ }^{1}$, Cheng-Ta Yang ${ }^{2}$, Chih-Hsi Scott Kuo ${ }^{2}$, Ping-Chih Hsu ${ }^{2}$ and John Wen-Cheng Chang ${ }^{1 *}$

\begin{abstract}
Background: Afatinib is one of the standard treatments for patients with epidermal growth factor receptor (EGFR)mutated non-small-cell lung cancer (NSCLC). However, data on the use of afatinib in patients with poor performance status (PS $\geq 2$ ) are limited. This study aimed to retrospectively review the clinical outcomes and safety of afatinib treatment in EGFR-mutation-positive (EGFRm+) NSCLC patients with PS $\geq 2$.

Methods: The data for 62 patients who were treated at Linkou Chang Gung Memorial Hospital from January 2010 to August 2019 were retrospectively reviewed. Patients' clinicopathological features were obtained, and univariate and multivariate analyses were performed to identify possible prognostic factors. Data on adverse events were collected to evaluate general tolerance for afatinib therapy.

Results: Until February 2020, the objective response rate, disease control rate, median progression-free survival (PFS), and overall survival (OS) were 58.1\% (36/62), 69.4\% (43/62), 8.8 months, and 12.9 months, respectively. The absence of liver metastasis (PFS: $p=0.044$; OS: $p=0.061$ ) and good disease control ( $p<0.001$ for PFS and OS) were independent favorable prognostic factors for PFS and OS. Bone metastasis $(p=0.036)$ and dose modification (reduction/interruption, $p=0.021$ ) were predictors of disease control.
\end{abstract}

Conclusion: Afatinib demonstrated acceptable efficacy and safety in the current cohort. This study provided evidence to support the use of afatinib as a first-line treatment in EGFRm+ NSCLC patients with poor PS.

Keywords: Lung cancer, Afatinib, EGFR, TKI, Performance status

\section{Background}

Activating mutations in the epidermal growth factor receptor (EGFR) gene in non-small-cell lung cancer (NSCLC) lead to an increase in growth factor signaling

\footnotetext{
*Correspondence: wen1902@hotmail.com

${ }^{\dagger}$ Chiao-En Wu and Ching-Fu Chang contributed equally to this work.

'Department of Internal Medicine, Division of Hematology-Oncology, Chang Gung Memorial Hospital at Linkou, Chang Gung University College of Medicine, No. 5, Fu-Hsing Street, Kwei-Shan District, Taoyuan City 333, Taiwan

Full list of author information is available at the end of the article
}

activity and susceptibility to tyrosine kinase inhibitors (TKIs) [1, 2]. First-generation EGFR-TKIs, such as gefitinib and erlotinib, have become the first-line treatment for patients with EGFR-mutation-positive (EGFRm+) NSCLC since 2010 [3-6]. Later, afatinib, a secondgeneration EGFR TKI, which serves as a pan-human EGFR(HER) family inhibitor that irreversibly binds to EGFR, was approved for the treatment of EGFRm+ NSCLC, based on the results of pivotal randomized clinical studies (LUX-Lung 3, LUX-Lung 6, and LUX-Lung

(c) The Author(s). 2021 Open Access This article is licensed under a Creative Commons Attribution 4.0 International License, which permits use, sharing, adaptation, distribution and reproduction in any medium or format, as long as you give appropriate credit to the original author(s) and the source, provide a link to the Creative Commons licence, and indicate if changes were made. The images or other third party material in this article are included in the article's Creative Commons licence, unless indicated otherwise in a credit line to the material. If material is not included in the article's Creative Commons licence and your intended use is not permitted by statutory regulation or exceeds the permitted use, you will need to obtain permission directly from the copyright holder. To view a copy of this licence, visit http://creativecommons.org/licenses/by/4.0/. The Creative Commons Public Domain Dedication waiver (http://creativecommons.org/publicdomain/zero/1.0/) applies to the data made available in this article, unless otherwise stated in a credit line to the data. 
7) [7-9]. Although osimertinib, a third-generation EGFR TKI, recently demonstrated superior survival outcomes compared with first-generation EGFR-TKIs (either gefitinib or erlotinib) as first-line treatment [10,11], afatinib remains widely used in daily practice due to its costeffectiveness.

Although patients are typically treated based on the outcomes of clinical trials, clinical trials typically apply restrictive inclusion and exclusion criteria, which cannot be completely applied to real-world practice; therefore, real-world experiences could provide additional information regarding the effectiveness of afatinib treatment in patients with EGFRm + NSCLC [12-15], particularly in those patients with the types of clinicopathological features that were excluded from previous clinical studies, such as uncommon EGFR mutations, brain metastases, advanced age, or poor performance status (PS) [16]. PS is an important prognostic and predictive factor in most cancer treatments. Previous clinical trials for afatinib only enrolled patients with good Eastern Cooperative Oncology Group (ECOG) PS scores of 0 or 1; therefore, the feasibility of afatinib in patients with poor PS remains unknown, although we treat these patients based on the outcomes of these clinical trials. In real-world cohorts, patients with PS $\geq 2$ account for $10-20 \%$ of all cases, and the number of patients with this score is limited [12, 13, 17-19]. Therefore, this study aimed to investigate the feasibility and efficacy of afatinib in patients with EGFRm+ NSCLC and poor PS (PS $\geq 2$ ).

\section{Methods}

\section{Data collection}

Data for all study patients were obtained from the Chang Gung Research Database [20], which is an integrated and comprehensive database consisting of multiinstitutional standardized electronic medical records from all Chang Gung Memorial Hospitals (CGMHs) in Taiwan, including information from the cancer registry. Data for patients were obtained from the cancer registry for Linkou CGMH from January 2010 to August 2019.

\section{Eligibility and exclusion criteria}

Patients who were diagnosed with advance (Stage IIIB and Stage IV, based on the American Joint Committee on Cancer staging system 7th edition) lung cancer [based on the International Disease Classification, 10th revision, Clinical Modification (ICD-10-CM) codes of C3400-C3492], with PS $\geq 2$, EGFR mutation, and who were treated with EGFR-TKIs as first-line treatment, without prior systemic treatment, were enrolled in the study. The EGFR mutation status of the tumors was retrospectively reviewed. Patients with single-nucleotide polymorphisms without activating mutation $(n=3)$ and those with a de novo T790M mutation $(n=7)$ were excluded. Finally, a total of 246 patients treated with various EGFR-TKIs as first-line treatment including 62 patients treated with afatinib were included in this study. This study was approved by the Institutional Review Board of CGMH (201901395B0). Patient consent to participate was not required due to the retrospective nature of this study.

\section{Patients' characteristics and treatment course}

The data of 62 patients who received afatinib as first-line treatment at Linkou CGMH were retrospectively reviewed. The clinicopathological features, including age, sex, body weight, height, smoking history, PS, tumor involvement, EGFR mutation (19del, L858R, or uncommon mutation), starting dose of afatinib, dose modification (reduction/interruption) of afatinib, tumor response, adverse events (AEs), and subsequent treatment were obtained. The last followup time point in the study was February 2020.

\section{Treatment and response evaluation}

The patients were treated with afatinib at a starting dose of either 30 or $40 \mathrm{mg}$, administered once daily until disease progression or intolerable toxicity. The dose and schedule of afatinib were adjusted by individual physicians based on the patients' clinical condition and AEs due to treatment. Tumor response was evaluated by chest radiography, computed tomography, or positron emission tomography. The Response Evaluation Criteria in Solid Tumors 1.1 criteria were used to evaluate the best tumor response. The best clinical tumor response was recorded as complete response (CR), partial response (PR), stable disease (SD), or progressive disease (PD). Any tumor response that was not assessed before death or discontinuation due to intolerance was recorded as "not assessed" (NA). Progression-free survival (PFS) was defined as the duration from the first day of afatinib treatment until the first radiological evidence of disease progression, the last dose of afatinib, death, or the latest follow-up time point. Those patients who did not experience progression nor death were censored during PFS analysis. Overall survival (OS) was defined as the duration from the first day of afatinib treatment until the date of death or last follow-up. The data for patients who did not experience death were censored when survival curves were analyzed. The objective response rate (ORR), expressed in percentage, was taken as the sum of $\mathrm{CR}$ and PR; the disease control rate (DCR), expressed in percentage, was taken as the sum of CR, PR, and SD.

\section{Adverse events}

Data about AEs were collected from electronic medical records and graded according to the National Cancer Institute Common Terminology Criteria for Adverse Events, version 4.0. All grades of AEs and severe AEs 
(Grades 3/4) were collected. Dose reductions, interruptions, or withdrawals due to the occurrence of AEs were recorded.

\section{Statistical analysis}

The PFS and OS were estimated using the Kaplan-Meier method and their prognostic factors were compared using the log-rank test. Univariate analysis was performed to evaluate possible prognostic factors including age, sex, staging, EGFR mutation status, PS, smoking history, body mass index (BMI), body surface area (BSA), tumor involvements, and clinical tumor response. Multivariate analysis was performed to evaluate independent prognostic factors. The results are presented as the hazard ratio (HR) and 95\% confidence interval (CI) from Cox regression analyses. IBM SPSS Statistics for Windows (Version 22.0, Armonk, NY, USA) was used to perform all statistical analyses, and $p<0.05$ was considered significant. We used the R package "survival" and "survminer" to plot survival curves and generate Cox proportional hazard models.

\section{Results}

\section{Patient characteristics}

In this study, a total of 62 EGFRm + NSCLC patients with ECOG PS $\geq 2$ who were treated with first-line afatinib as a systemic treatment were examined. The patients' ages ranged from 36.6 to 89.0 years, with a median age of 66.7 years, $22(35.5 \%)$ were men, and 40 (64.5\%) were women, and all patients were Asians. All patients had Stage IV disease, except one who had Stage IIIb disease, according to the American Joint Committee on Cancer staging system 7th edition. Fifty-two patients (85.2\%) had no smoking history. The tumor histology for all patients was adenocarcinoma. Thirty-eight (61.3\%) patients had a PS of 2, whereas 24 (38.7\%) patients had a PS $>2$. The EGFR mutation identified most frequently were L858R $(n=30,48.4 \%)$ and 19del $(n=25$, $40.3 \%)$, and $7(11.3 \%)$ patients had uncommon EGFR mutations. In terms of tumor involvement, bone was the most common metastatic site (51.6\%), followed by lung (43.5\%) and brain (43.5\%). The starting dose for 39 (62.9\%) patients was $40 \mathrm{mg}$ afatinib daily, whereas the starting dose for $23(37.1 \%)$ patients was $30 \mathrm{mg}$ afatinib daily (Table 1).

By the end of February 2020, the follow-up time ranged from 0.3 to 64.5 months, with a median followup time of 13.1 months. The median PFS (mPFS) and median OS (mOS) were 8.8 months (95\% CI: 6.78-10.77 months) and 12.9 months (95\% CI: $8.35-17.35$ months), respectively (Fig. 1). The ORR was $58.1 \%(n=36)$ and the DCR was $69.4 \%(n=43)$.

\section{Prognostic factors for PFS}

A univariate analysis was performed to identify possible prognostic factors for PFS in patients treated with afatinib. Patients who received a starting dose of $40 \mathrm{mg}$ (vs. $30 \mathrm{mg}$, mPFS: 10.8 vs. 6.7 months, HR: 0.55, 95\% CI: $0.31-0.98, p=0.043$ ) had favorable PFS (Fig. 2A). Patients who experienced liver metastases (vs. no liver metastases, mPFS: 3.1 vs. 9.9 months, HR: 1.94, 95\% CI: $1.02-3.69, p=0.044$; Fig. $2 \mathrm{C}$ ) and pleural metastases (vs. no pleural metastases, mPFS: 8.1 vs. 10.2 months, HR: 1.92, 95\% CI: $1.07-3.45, p=0.03$; Fig. 3A) had unfavorable PFS. Patients who achieved CR/PR (vs. PD/NA, mPFS: 11.8 vs. 1.4 months, HR: 0.05, 95\% CI: 0.02-0.13, $p<0.001$ ) or SD (vs. PD/NA, mPFS: 18.4 vs. 1.4 months, HR: $0.04,95 \%$ CI: $0.01-0.14, p<0.001)$ showed better PFS than those with a tumor response of PD/NA (Fig. 2E and Table 2).

A multivariate analysis was further performed to determine the independent prognostic factors for PFS. Liver metastases (vs. no liver metastases, HR: 2.17, 95\% CI: $1.11-4.26, p=0.023$ ) and tumor responses of $\mathrm{CR} / \mathrm{PR}$ (vs. PD/NA, HR: 0.05, 95\% CI: 0.02-0.13, $p<0.001$ ) and SD (vs. PD/NA, HR: 0.05, 95\% CI: 0.01-0.19, $p<0.001$ ) were identified as independent prognostic factors for PFS (Table 2).

\section{Prognostic factors for OS}

A univariate analysis was performed to identify the possible prognostic factors for OS in patients treated with afatinib. Patients with a starting afatinib dose of $40 \mathrm{mg}$ (vs. $30 \mathrm{mg}$, mOS: 17.5 vs. 8.1 months, HR: $0.59,95 \% \mathrm{CI}$ : 0.34-1.05, $p=0.073$ ) showed favorable OS (Fig. 2B). Patients who had liver metastases (vs. no liver metastases, mOS: 3.1 vs. 13.8 months, HR: 1.85, 95\% CI: 0.97-3.52, $p=0.061$ ) showed unfavorable OS (Fig. 2D). Patients who achieved CR/PR (vs. PD/NA, mOS: 18.1 vs. 1.4 months, HR: 0.15 , 95\% CI: $0.08-0.3, p<0.001$ ) or SD (vs. PD/NA, mOS: 20.3 vs. 1.4 months, HR: 0.14, 95\% CI: 0.05-0.39, $p<0.001$ ) had better OS than those who had PD/NA (Fig. 2F).

Because only tumor response was significant on univariate analysis, those prognostic factors with $p<0.1$ were included in the multivariate analysis to identify potential independent prognostic factors for OS. Liver metastases (vs. no liver metastases, HR: 2.15, 95\% CI: $1.1-$ $4.18, p=0.024$ ) and tumor responses of CR/PR (vs. PD/ NA, HR: $0.14,95 \%$ CI: $0.05-0.42, p<0.001$ ) and SD (vs. PD/NA, HR: $0.14,95 \%$ CI: $0.07-0.30, p<0.001)$ were independent prognostic factors for OS (Table 3 ).

\section{Predictive factors for tumor response}

In this study, patients with SD had comparable survival outcomes as patients with CR/PR; therefore, achieving durable disease control rather might be more important 
Table 1 Patient's characteristics and associations with clinical response

\begin{tabular}{|c|c|c|c|c|}
\hline \multirow[t]{2}{*}{ Characteristics } & \multirow[t]{2}{*}{ Total $(N=62)$} & \multicolumn{2}{|l|}{ Response } & \multirow[t]{2}{*}{$p$-value } \\
\hline & & CR/PR/SD $(N=47)$ & PD/NA $(N=15)$ & \\
\hline Age, median (IQR) & $66.7(18.1)$ & $65.1(19.5)$ & $71.2(16.1)$ & 0.42 \\
\hline$\leq 65$ & $27(43.5 \%)$ & $23(85.2 \%)$ & $4(14.8 \%)$ & 0.13 \\
\hline$>65$ & $35(56.5 \%)$ & $24(68.6 \%)$ & $11(31.4 \%)$ & \\
\hline \multicolumn{5}{|l|}{ Sex } \\
\hline Male & $22(35.5 \%)$ & $16(72.7 \%)$ & $6(27.3 \%)$ & 0.675 \\
\hline Female & $40(64.5 \%)$ & $31(77.5 \%)$ & $9(22.5 \%)$ & \\
\hline \multicolumn{5}{|l|}{ Stage } \\
\hline Stage 3B & $1(1.6 \%)$ & $1(100.0 \%)$ & $0(0.0 \%)$ & 0.569 \\
\hline Stage 4 & $61(98.4 \%)$ & $46(75.4 \%)$ & $15(24.6 \%)$ & \\
\hline \multicolumn{5}{|l|}{ Smoking status ${ }^{\mathrm{a}}$} \\
\hline Smoker & $9(14.8 \%)$ & $8(88.9 \%)$ & $1(11.1 \%)$ & 0.36 \\
\hline Never smoker & $52(85.2 \%)$ & $39(75.0 \%)$ & $13(25.0 \%)$ & \\
\hline \multicolumn{5}{|l|}{ Histology } \\
\hline Adenocarcinoma & $62(100.0 \%)$ & $47(75.8 \%)$ & $15(24.2 \%)$ & - \\
\hline \multicolumn{5}{|c|}{ Performance status, PS } \\
\hline PS 2 & $38(61.3 \%)$ & $28(73.7 \%)$ & $10(26.3 \%)$ & 0.623 \\
\hline PS $3 / 4$ & $24(38.7 \%)$ & $19(79.2 \%)$ & $5(20.8 \%)$ & \\
\hline \multicolumn{5}{|l|}{ Mutation } \\
\hline L858R & $30(48.4 \%)$ & $24(80.0 \%)$ & $6(20.0 \%)$ & 0.097 \\
\hline 19del & $25(40.3 \%)$ & $20(80.0 \%)$ & $5(20.0 \%)$ & \\
\hline Uncommon & 7 (11.3\%) & $3(42.9 \%)$ & $4(57.1 \%)$ & \\
\hline \multicolumn{5}{|l|}{ Starting dose } \\
\hline $40 \mathrm{mg}$ & $39(62.9 \%)$ & $31(79.5 \%)$ & $8(20.5 \%)$ & 0.378 \\
\hline $30 \mathrm{mg}$ & $23(37.1 \%)$ & $16(69.6 \%)$ & 7 (30.4\%) & \\
\hline \multicolumn{5}{|l|}{ Metastatic sites } \\
\hline \multicolumn{5}{|l|}{ Lung } \\
\hline Yes & $27(43.5 \%)$ & $19(70.4 \%)$ & $8(29.6 \%)$ & 0.38 \\
\hline No & 35 (56.5\%) & $28(80.0 \%)$ & 7 (20.0\%) & \\
\hline \multicolumn{5}{|l|}{ Liver } \\
\hline Yes & $14(22.6 \%)$ & $10(71.4 \%)$ & $4(28.6 \%)$ & 0.664 \\
\hline No & 48 (77.4\%) & 37 (77.1\%) & 11 (22.9\%) & \\
\hline \multicolumn{5}{|l|}{ Brain } \\
\hline Yes & $27(43.5 \%)$ & $19(70.4 \%)$ & $8(29.6 \%)$ & 0.38 \\
\hline No & 35 (56.5\%) & $28(80.0 \%)$ & 7 (20.0\%) & \\
\hline \multicolumn{5}{|l|}{ Bone } \\
\hline Yes & $32(51.6 \%)$ & $28(87.5 \%)$ & $4(12.5 \%)$ & 0.026 \\
\hline No & $30(48.4 \%)$ & $19(63.3 \%)$ & $11(36.7 \%)$ & \\
\hline \multicolumn{5}{|l|}{ Pleura } \\
\hline Yes & 21 (33.9\%) & $16(76.2 \%)$ & 5 (23.8\%) & 0.96 \\
\hline No & 41 (66.1\%) & $31(75.6 \%)$ & $10(24.4 \%)$ & \\
\hline \multicolumn{5}{|l|}{ Adrenal gland } \\
\hline Yes & $4(6.5 \%)$ & $3(75.0 \%)$ & $1(25.0 \%)$ & 0.969 \\
\hline No & 58 (93.5\%) & 44 (75.9\%) & 14 (24.1\%) & \\
\hline
\end{tabular}


Table 1 Patient's characteristics and associations with clinical response (Continued)

\begin{tabular}{|c|c|c|c|c|}
\hline \multirow[t]{2}{*}{ Characteristics } & \multirow[t]{2}{*}{ Total $(N=62)$} & \multicolumn{2}{|l|}{ Response } & \multirow[t]{2}{*}{$p$-value } \\
\hline & & CR/PR/SD $(N=47)$ & PD/NA $(N=15)$ & \\
\hline \multicolumn{5}{|c|}{ Distant lymphadenopathy } \\
\hline Yes & $6(9.7 \%)$ & $4(66.7 \%)$ & $2(33.3 \%)$ & \multirow[t]{2}{*}{0.582} \\
\hline No & $56(90.3 \%)$ & $43(76.8 \%)$ & $13(23.2 \%)$ & \\
\hline \multicolumn{5}{|c|}{ Dose reduction/interruption } \\
\hline Yes & $23(37.1 \%)$ & $21(91.3 \%)$ & $2(8.7 \%)$ & \multirow[t]{2}{*}{0.029} \\
\hline No & $39(62.9 \%)$ & $26(66.7 \%)$ & $13(33.3 \%)$ & \\
\hline \multicolumn{5}{|c|}{ Discontinuation, AE-related } \\
\hline Yes & $8(12.9 \%)$ & $5(62.5 \%)$ & $3(37.5 \%)$ & \multirow[t]{2}{*}{0.346} \\
\hline No & $54(87.1 \%)$ & $42(77.8 \%)$ & $12(22.2 \%)$ & \\
\hline BMI, median (IQR) & $23.11(4.50)$ & $22.68(3.75)$ & $25.98(8.46)$ & 0.059 \\
\hline BSA, median (IQR) & $1.57(0.17)$ & $1.57(0.17)$ & $1.60(0.20)$ & 0.48 \\
\hline
\end{tabular}

$I Q R$ interquartile range, $C R$ complete response, $P R$ partial response, $S D$ stable disease, $P D$ progressive disease, $N A$ not assessed, $B M I$ body mass index, $B S A$ body surface area, $A E$ adverse events

${ }^{\text {a }}$ There is one missing data point on smoking status

for patients with poor PS than a profound objective response. Therefore, potential predictors of disease control were investigated (Table 1). Bone metastasis (DCR: $81.3 \%$ vs $56.7 \%, p=0.036$ ) and dose reduction/ interruption due to AEs (DCR: $87.0 \%$ vs. $59.0 \%, p=$ 0.021) were the only predictors for disease control identified in this cohort. Patients with a starting dose of $40 \mathrm{mg}$ (DCR for $40 \mathrm{mg}$ vs. $30 \mathrm{mg}: 76.9 \%$ vs. $56.5 \%$, $p=0.092)$, lower BMI (22.1 vs. $25.3, p=0.063)$, and younger age (median age: 62.8 years in the DCR group and 74.3 years in the PD/NA group, $p=0.091$; DCR for patients $<65$ years vs. $\geq 65$ years, $81.5 \%$ vs.. $60.0 \%, p=0.069)$ trended to have more disease control than those without these features.

\section{Adverse events and association with the starting dose of} afatinib

Diarrhea (87.1\%) was the most frequently reported $\mathrm{AE}$, followed by skin rashes (62.9\%), paronychia (45.2\%), and mucositis/stomatitis (38.7\%). Most reported AEs were mild (Grade 1/2) and manageable. Among severe (Grade $\geq 3$ ) AEs, diarrhea (11.3\%) remained the most frequently reported AE, followed by paronychia (9.7\%), mucositis/stomatitis (6.5\%), and skin rashes (4.8\%). Overall, treatment with $40 \mathrm{mg}$ afatinib was more likely to be associated with the occurrence of all grades of AEs $(100 \%$ vs $91.3 \%, p=0.061)$ and severe AEs $(30.8 \%$ vs $8.7 \%, p=$ $0.045)$ than treatment with $30 \mathrm{mg}$. For specific AEs, such as diarrhea, paronychia, skin lesions, and mucositis,
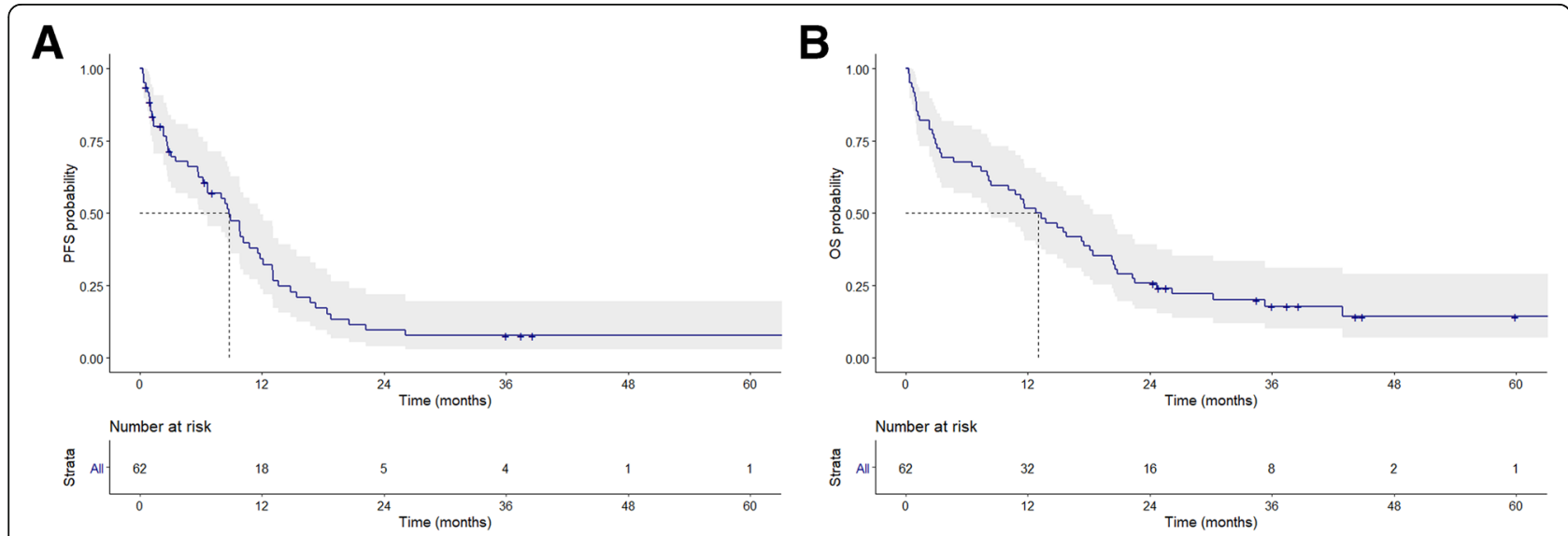

Fig. 1 Kaplan-Meier survival curves for PFS (A) and OS (B) among patients treated with afatinib. PFS, progression-free survival; OS, overall survival 

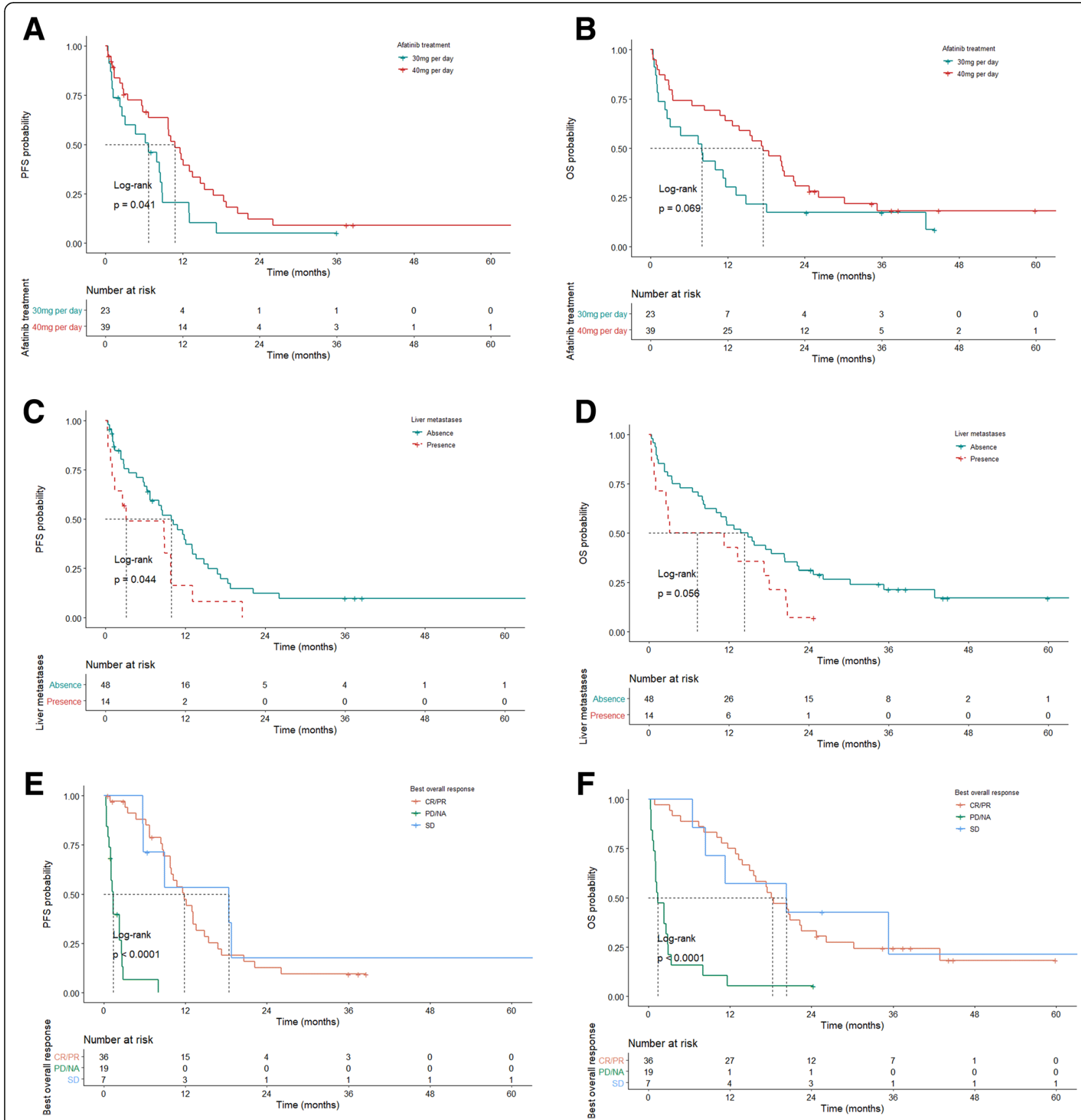

Fig. 2 Kaplan-Meier survival curves for PFS (A, C, and $\mathbf{E}$ ) and OS (B, D, and $\mathbf{F})$ among patients stratified according to prognostic factors: starting dose of afatinib (A and $\mathbf{B}$ ), liver metastases (C and $\mathbf{D})$, and clinical tumor responses (E and $\mathbf{F})$. PFS, progression-free survival; OS, overall survival; $\mathrm{CR}$, complete response; PR, partial response; SD, stable disease, PD progressive disease; NA, not assessed

treatment with $40 \mathrm{mg}$ afatinib was associated with a higher incidence of AEs than treatment with $30 \mathrm{mg}$ afatinib, although this difference was not significant, likely due to the limited number of cases (Table 4).

\section{Subsequent treatment after afatinib}

Overall, 25 (40.3\%) patients received subsequent treatment after afatinib failure, including chemotherapy $(n=14)$, TKIs other than osimertinib $(n=14)$, osimertinib $(n=4)$, bevacizumab $(n=3)$, and immune checkpoint inhibitors $(n=2)$. No significant association was found between the starting afatinib dose, tumor response, and subsequent treatment; however, patients with $\mathrm{PD} / \mathrm{NA}$ were more likely to receive subsequent immunotherapy $(10.5 \%$ vs. $0.0 \%, p=0.031)$, which was not clinically significant because only 2 of 62 patients received subsequent immunotherapy (Table 5). 

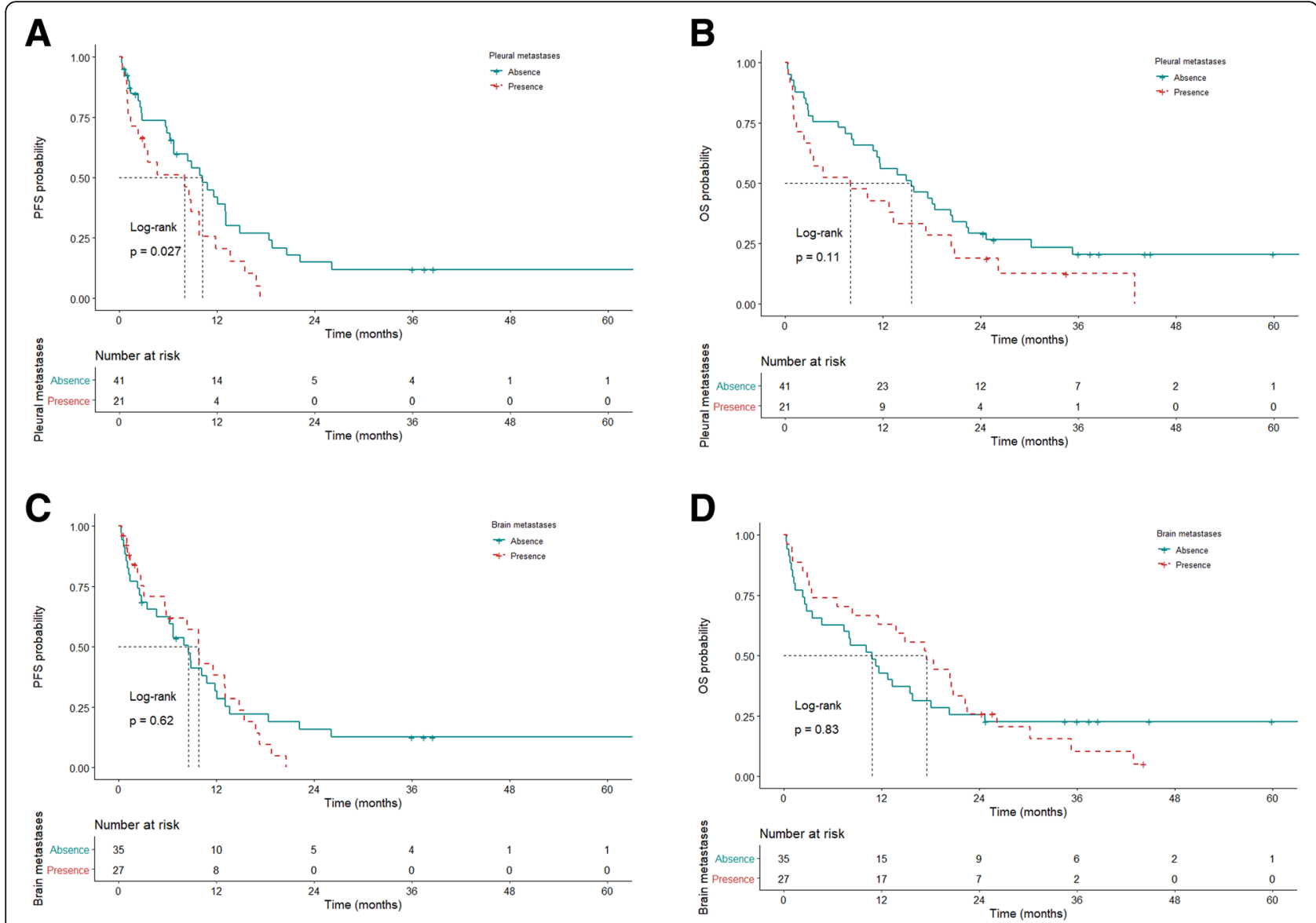

Fig. 3 Kaplan-Meier survival curves for PFS (A and $\mathbf{C}$ ) and OS (B and $\mathbf{D})$ among patients stratified according to pleural metastasis (A and $\mathbf{B})$ and brain metastasis (C and $\mathbf{D}$ ). PFS, progression-free survival; OS, overall survival

\section{Discussion}

To the best of our knowledge, this is the largest cohort study to investigate the feasibility and efficacy of afatinib treatment for EGFRm + NSCLC patients with PS $\geq 2$ because these patients have been excluded from previous clinical trials. This real-world experience from a single institute demonstrated that afatinib was effective and well-tolerated among patients with poor PS. The ORR, DCR, mPFS, and mOS were 58.1, 69.4\%, 8.8 months, and 12.9 months, respectively. Dose modification and discontinuation frequently occurred but did not compromise clinical benefits. Treatment-related AEs frequently occurred, but most were mild and tolerable. In addition, liver metastasis and clinical tumor response were identified as independent prognostic factors for PFS and OS. Furthermore, bone metastasis and dose modification (reduction/interruption) were the only predictors for disease control. This study provided additional evidence to support the use of afatinib in patients with poor PS.

The major causes of poor PS in NSCLC patients were underlying comorbidities and disseminated/advanced NSCLC; therefore, these patients may only have one line of treatment option and might not receive subsequent treatment if their tumors do not respond to afatinib treatment. In our analysis, clinical tumor response was the most important prognostic factor for survival, and patients who did not achieve disease control after afatinib treatment had a worse prognosis (mPFS: 1.4 months, mOS: 1.5 months). In addition, patients who developed metastasis at specific sites were associated with shorter mPFS and mOS, except those with bone and brain metastases (Tables 2 and 3 and Fig. 3). This outcome could be explained by the finding that afatinib is effective for patients with bone and brain metastases [18]; therefore, poor PS caused by bone and brain metastases may be reversed by afatinib. Systemic treatments other than TKIs are effective in patients with good PS without brain metastasis; however, in the absence of brain metastasis, the outcomes of patients with poor PS in our study might not be comparable to that of patients with good PS in other studies [18]. This difference may be due to poor PS (which is a result of greater toxicity and lower response rates) undermining the efficacy of subsequent systemic treatment. 
Table 2 Univariate and multivariate analysis of prognostic factors in patients (PFS)

\begin{tabular}{|c|c|c|c|c|c|c|c|c|}
\hline \multirow[t]{2}{*}{ Parameters } & \multicolumn{5}{|l|}{ Univariate } & \multicolumn{3}{|c|}{ Multivariate } \\
\hline & Median (months) & $95 \% \mathrm{Cl}$ & HR & $95 \% \mathrm{Cl}$ & $\overline{p \text {-value }}$ & HR & $95 \% \mathrm{Cl}$ & $p$-value \\
\hline \multicolumn{9}{|l|}{ Age } \\
\hline$\leq 65$ & 9.9 & $7.8-12.0$ & 0.95 & $0.54-1.66$ & 0.862 & & & \\
\hline$>65$ & 8.1 & $1.2-15.0$ & & & & & & \\
\hline \multicolumn{9}{|l|}{ Sex } \\
\hline Male & 11.6 & $7.2-16.1$ & 0.66 & $0.37-1.16$ & 0.15 & & & \\
\hline Female & 6.7 & $3.2-10.2$ & & & & & & \\
\hline \multicolumn{9}{|l|}{ Smoking status ${ }^{\mathrm{a}}$} \\
\hline Smoker & 14.8 & $10.1-19.5$ & 0.54 & $0.25-1.16$ & 0.113 & & & \\
\hline Never smoker & 8.1 & $5.5-10.6$ & & & & & & \\
\hline \multicolumn{9}{|c|}{ Performance status, PS } \\
\hline PS 2 & 9.9 & $8.4-11.4$ & 0.94 & $0.52-1.69$ & 0.826 & & & \\
\hline PS $3 / 4$ & 6.2 & $5.0-7.5$ & & & & & & \\
\hline Mutation & & & & & 0.446 & & & \\
\hline L858R & 8.4 & $5.2-11.5$ & 0.77 & $0.33-1.80$ & 0.548 & & & \\
\hline 19del & 10.2 & $7.3-13.1$ & 0.59 & $0.25-1.41$ & 0.235 & & & \\
\hline Uncommon & 3.5 & $0.5-6.6$ & & & & & & \\
\hline \multicolumn{9}{|l|}{ Starting dose } \\
\hline $40 \mathrm{mg}$ & 10.8 & $8.6-13.1$ & 0.55 & $0.31-0.98$ & 0.043 & 0.92 & $0.49-1.75$ & 0.806 \\
\hline $30 \mathrm{mg}$ & 6.7 & $1.9-11.5$ & & & & & & \\
\hline \multicolumn{9}{|l|}{ Metastatic sites } \\
\hline \multicolumn{9}{|l|}{ Lung } \\
\hline Yes & 8.1 & $5.5-10.6$ & 1.41 & $0.81-2.46$ & 0.222 & & & \\
\hline No & 9.9 & $8.5-11.3$ & & & & & & \\
\hline \multicolumn{9}{|l|}{ Liver } \\
\hline Yes & 3.1 & $0.0-13.3$ & 1.94 & $1.02-3.69$ & 0.044 & 2.17 & $1.11-4.26$ & 0.023 \\
\hline No & 9.9 & $6.5-13.3$ & & & & & & \\
\hline \multicolumn{9}{|l|}{ Brain } \\
\hline Yes & 9.8 & $7.6-12.0$ & 1.16 & $0.66-2.04$ & 0.615 & & & \\
\hline No & 8.6 & $5.8-11.5$ & & & & & & \\
\hline \multicolumn{9}{|l|}{ Bone } \\
\hline Yes & 9.8 & $8.1-11.5$ & 0.65 & $0.38-1.14$ & 0.133 & & & \\
\hline No & 5.9 & $1.4-10.2$ & & & & & & \\
\hline \multicolumn{9}{|l|}{ Pleura } \\
\hline Yes & 8.1 & $0.8-15.3$ & 1.92 & $1.07-3.45$ & 0.03 & 1.58 & $0.84-2.98$ & 0.157 \\
\hline No & 10.2 & $6.8-13.6$ & & & & & & \\
\hline \multicolumn{9}{|l|}{ Adrenal gland } \\
\hline Yes & 8.6 & $0.0-21.1$ & 1.13 & $0.35-3.64$ & 0.842 & & & \\
\hline No & 8.9 & $5.4-12.3$ & & & & & & \\
\hline \multicolumn{9}{|c|}{ Distant lymphadenopathy } \\
\hline Yes & 6.7 & $0.0-15.9$ & 1.91 & $0.74-4.94$ & 0.183 & & & \\
\hline No & 8.9 & $7.0-10.8$ & & & & & & \\
\hline \multicolumn{9}{|c|}{ Dose reduction/interruption } \\
\hline Yes & 11.6 & $9.0-14.3$ & 0.65 & $0.36-1.16$ & 0.143 & & & \\
\hline
\end{tabular}


Table 2 Univariate and multivariate analysis of prognostic factors in patients (PFS) (Continued)

\begin{tabular}{|c|c|c|c|c|c|c|c|c|}
\hline \multirow[t]{2}{*}{ Parameters } & \multicolumn{5}{|l|}{ Univariate } & \multicolumn{3}{|c|}{ Multivariate } \\
\hline & Median (months) & $95 \% \mathrm{Cl}$ & HR & $95 \% \mathrm{Cl}$ & $p$-value & HR & $95 \% \mathrm{Cl}$ & $p$-value \\
\hline No & 6.2 & $0.0-12.7$ & & & & & & \\
\hline \multicolumn{9}{|c|}{ Discontinuation, AE-related } \\
\hline Yes & 6.7 & $0.6-12.8$ & 0.64 & $0.20-2.07$ & 0.457 & & & \\
\hline No & 8.9 & $6.9-10.8$ & & & & & & \\
\hline Clinical tumor response & & & & & $<0.001$ & & & $<0.001$ \\
\hline CR/PR & 11.8 & $9.2-14.4$ & 0.05 & $0.02-0.13$ & $<0.001$ & 0.05 & $0.02-0.13$ & $<0.001$ \\
\hline SD & 18.4 & $4.7-32.1$ & 0.04 & $0.01-0.14$ & $<0.001$ & 0.05 & $0.01-0.19$ & $<0.001$ \\
\hline $\mathrm{PD} / \mathrm{NA}$ & 1.4 & $0.9-1.8$ & & & & & & \\
\hline BMI & & & 1.05 & $0.97-1.13$ & 0.244 & & & \\
\hline BSA & & & 0.1 & $0.01-2.02$ & 0.132 & & & \\
\hline
\end{tabular}

$I Q R$ interquartile range, $C R$ complete response, $P R$ partial response, $S D$ stable disease, $P D$ progressive disease, $N A$ not assessed, $H R$ hazard ratio, $C I$ confidence interval, $B M I$ body mass index, $B S A$ body surface area, PFS progression-free survival, $A E$ adverse events

${ }^{a}$ There is one missing data point on smoking status

A large cohort study based on the Taiwan Cancer Registry, conducted in 2011-2015, compared the efficacy of three different TKIs-gefitinib, erlotinib, and afatinin. The results showed a time to treatment failure (TTF) and an OS of 15.8 months and not reached, respectively, for afatinib treatment during the median followup period of 17.3 months [21]. Median event-free survivals indicated the time when $50 \%$ of patients had reached the events. If less than $50 \%$ of the patients were alive during the follow-up, this would be recorded as "not reach." Seventy-three of seven hundred fifty-one patients who received afatinib had a PS of 2, and those with PS $>2$ were excluded from this study. A PS of 2 was an independent prognostic factor for TTF and OS, but detailed data were not available. In addition, data on response evaluation, PFS, AEs, EGFR mutation type, and tumor involvement were not reported, which are the major limitations of retrospective cohort studies performed using data from the Cancer Registry databank.

Liver metastasis was an independent unfavorable prognostic factor. Patients with liver metastasis had worse survival outcomes (mPFS: 3.1 months and mOS: 3.1 months) compared with patients without liver metastases, which agreed with previous studies. A study demonstrated that the mPFS was only 2.3 months in EGFRm+ patients with liver metastases treated with erlotinib as second- or third-line treatment [22]. Another study reported that liver metastasis was a significantly poor prognostic factor, with mPFS and mOS of 5.9 and 11.9 months, respectively, in EGFRm+ patients with liver metastases treated with first-line TKIs [23].

In clinical practice, physicians usually prescribe a fixed dose of TKI therapy rather than a formulated dose as is used in chemotherapy. In this study, the starting dose of $40 \mathrm{mg}$ was associated with good disease control and favorable PFS and OS. In addition, AE-related dose modification (reduction/interruption) was a predictor of better disease control and longer mPFS and mOS. Furthermore, patients whose tumors achieved disease control had a trend toward lower BMI than those who did not achieve disease control (22.1 vs. $25.3, p=0.063$ ). These findings indicated that dose and BMI might be used to predict the clinical benefit and associated AEs; therefore, the association among survival outcomes, dose, and BMI should be investigated in a larger cohort.

The frequency of AEs may be underestimated in this study due to its retrospective nature; however, the frequency of AEs in this study was much higher than those reported in previous real-world studies $[19,24]$. Although $37.1 \%$ of patients required dose modifications and $12.9 \%$ required treatment discontinuation, their survival outcomes were not affected by treatment interruption. Furthermore, patients with dose modifications showed trends toward longer PFS and OS compared with those without dose modifications. This finding suggested that dose modification in patients who were intolerant to AEs did not compromise the treatment outcomes of those patients. Patients who discontinued afatinib treatment typically received first-generation TKIs, such as gefitinib, as a subsequent treatment, which have been associated with fewer AEs than afatinib [9].

Patients with an initial $40 \mathrm{mg}$ dose had longer PFS $(p=0.043)$ and OS $(p=0.073)$ than those who started at $30 \mathrm{mg}$. However, this finding was not considered significant in the multivariate analysis. In addition, treatment with $40 \mathrm{mg}$ afatinib induced more AEs than treatment with $30 \mathrm{mg}$ afatinib in the current cohort. In a study of 48 patients, those who received $30 \mathrm{mg}$ 
Table 3 Univariate and multivariate analysis of prognostic factors in patients (OS)

\begin{tabular}{|c|c|c|c|c|c|c|c|c|}
\hline \multirow[t]{2}{*}{ Parameters } & \multicolumn{2}{|l|}{ Univariate } & \multirow[b]{2}{*}{ HR } & \multirow[b]{2}{*}{$95 \% \mathrm{Cl}$} & \multirow[b]{2}{*}{$p$-value } & \multicolumn{3}{|c|}{ Multivariate } \\
\hline & Median (months) & $95 \% \mathrm{Cl}$ & & & & $\overline{\mathrm{HR}}$ & $95 \% \mathrm{Cl}$ & $\overline{p \text {-value }}$ \\
\hline \multicolumn{9}{|l|}{ Age } \\
\hline$\leq 65$ & 15.8 & $10.3-21.4$ & 0.91 & $1.59-0.52$ & 0.744 & & & \\
\hline$>65$ & 8.2 & $1.1-15.3$ & & & & & & \\
\hline \multicolumn{9}{|l|}{ Sex } \\
\hline Male & 13.3 & $3.8-22.9$ & 0.77 & $0.43-1.38$ & 0.375 & & & \\
\hline Female & 11.6 & $5.3-17.8$ & & & & & & \\
\hline \multicolumn{9}{|l|}{ Smoking status } \\
\hline Smoker & 22.3 & $16.7-27.9$ & 0.62 & $0.28-1.39$ & 0.244 & & & \\
\hline Never smoker & 11.3 & $5.5-17.0$ & & & & & & \\
\hline \multicolumn{9}{|c|}{ Performance status, PS } \\
\hline PS 2 & 15.8 & $8.8-22.9$ & 0.86 & $0.49-1.53$ & 0.615 & & & \\
\hline PS $3 / 4$ & 8.4 & $2.3-14.6$ & & & & & & \\
\hline Mutation & & & & & 0.52 & & & \\
\hline L858R & 11.7 & $7.7-15.6$ & 0.67 & $0.27-1.65$ & 0.382 & & & \\
\hline 19del & 18.1 & $9.1-27.1$ & 0.59 & $0.24-1.46$ & 0.253 & & & \\
\hline Uncommon & 3.5 & $0.5-6.6$ & & & & & & \\
\hline \multicolumn{9}{|l|}{ Starting dose } \\
\hline $40 \mathrm{mg}$ & 17.5 & $11.6-23.4$ & 0.59 & $0.34-1.05$ & 0.073 & 0.93 & $0.51-1.72$ & 0.827 \\
\hline $30 \mathrm{mg}$ & 8.1 & $2.6-13.5$ & & & & & & \\
\hline \multicolumn{9}{|l|}{ Metastatic sites } \\
\hline \multicolumn{9}{|l|}{ Lung } \\
\hline Yes & 10.1 & $4.9-15.2$ & 1.26 & $0.72-2.19$ & 0.422 & & & \\
\hline No & 15.8 & $11.0-20.7$ & & & & & & \\
\hline \multicolumn{9}{|l|}{ Liver } \\
\hline Yes & 3.1 & $0.0-18.5$ & 1.85 & $0.97-3.52$ & 0.061 & 2.15 & $1.1-4.18$ & 0.024 \\
\hline No & 13.8 & 8.9-18.6 & & & & & & \\
\hline \multicolumn{9}{|l|}{ Brain } \\
\hline Yes & 17.5 & $11.6-23.4$ & 0.94 & $0.54-1.64$ & 0.838 & & & \\
\hline No & 10.8 & $6.7-15.0$ & & & & & & \\
\hline \multicolumn{9}{|l|}{ Bone } \\
\hline Yes & 18.1 & $11.5-24.8$ & 0.66 & $0.38-1.15$ & 0.147 & & & \\
\hline No & 8.4 & $1.7-15.2$ & & & & & & \\
\hline \multicolumn{9}{|l|}{ Pleura } \\
\hline Yes & 8.1 & $0.0-17.8$ & 1.59 & $0.90-2.81$ & 0.112 & & & \\
\hline No & 15.5 & $8.2-22.8$ & & & & & & \\
\hline \multicolumn{9}{|l|}{ Adrenal gland } \\
\hline Yes & 10.1 & $0.0-29.7$ & 1.28 & $0.46-3.55$ & 0.641 & & & \\
\hline No & 12.9 & $8.4-17.3$ & & & & & & \\
\hline \multicolumn{9}{|c|}{ Distant lymphadenopathy } \\
\hline Yes & 15.5 & $0.0-39.8$ & 1.11 & $0.47-2.62$ & 0.804 & & & \\
\hline No & 11.7 & $8.1-15.2$ & & & & & & \\
\hline \multicolumn{9}{|c|}{ Dose reduction/interruption } \\
\hline Yes & 20.3 & $15.8-24.8$ & 0.65 & $0.37-1.15$ & 0.138 & & & \\
\hline
\end{tabular}


Table 3 Univariate and multivariate analysis of prognostic factors in patients (OS) (Continued)

\begin{tabular}{|c|c|c|c|c|c|c|c|c|}
\hline \multirow[t]{2}{*}{ Parameters } & \multicolumn{2}{|l|}{ Univariate } & \multirow[b]{2}{*}{ HR } & \multirow[b]{2}{*}{$95 \% \mathrm{Cl}$} & \multirow[b]{2}{*}{$p$-value } & \multicolumn{3}{|c|}{ Multivariate } \\
\hline & Median (months) & $95 \% \mathrm{Cl}$ & & & & $\overline{H R}$ & $95 \% \mathrm{Cl}$ & $\overline{p \text {-value }}$ \\
\hline No & 8.1 & $0.1-16.1$ & & & & & & \\
\hline \multicolumn{9}{|c|}{ Discontinuation, AE-related } \\
\hline Yes & 17.5 & $0.0-38.6$ & 0.59 & $0.23-1.48$ & 0.261 & & & \\
\hline No & 11.7 & $8.2-15.2$ & & & & & & \\
\hline Clinical tumor response & & & & & $<0.001$ & & & $<0.001$ \\
\hline CR/PR & 18.1 & $13.6-22.7$ & 0.15 & $0.08-0.3$ & $<0.001$ & 0.14 & $0.05-0.42$ & $<0.001$ \\
\hline SD & 20.3 & $0.0-43.5$ & 0.14 & $0.05-0.39$ & $<0.001$ & 0.14 & $0.07-0.30$ & $<0.001$ \\
\hline $\mathrm{PD} / \mathrm{NA}$ & 1.5 & $0.0-3.1$ & & & & & & \\
\hline BMI & & & 1.01 & $0.93-1.10$ & 0.867 & & & \\
\hline BSA & & & 0.33 & $0.02-5.99$ & 0.451 & & & \\
\hline
\end{tabular}

$C R$ complete response, $P R$ partial response, $S D$ stable disease, $P D$ progressive disease, $N A$ not assessed, $A E$ adverse events, $B M I$ body mass index, $B S A$ body surface area, $H R$ hazard ratio, $\mathrm{Cl}$ confidence interval, $O S$ overall survival

daily as the initial dose tended to be older, female, and have a smaller body size [25]. Patients with an initial dose of $40 \mathrm{mg}$ afatinib daily showed no significant differences in ORR, DCR, or PFS compared with those who started with an initial dose of $30 \mathrm{mg}$ afatinib daily. Patients receiving $30 \mathrm{mg}$ daily had a significantly lower incidence of diarrhea than those receiving $40 \mathrm{mg}$ daily $(41 \%$ vs. $100 \%, p<0.0001)$ [25]. Other studies also reported no differences in clinical outcomes between 30 and $40 \mathrm{mg}$ doses of afatinib [12, 26].

The retrospective nature of this study and the limited number of patients were the major study limitations; however, to the best of our knowledge, this study represents the largest cohort study enrolling patients with $\mathrm{PS} \geq 2$ receiving afatinib. The causes of poor PS were difficult to determine, which represents one of the limitations of a retrospective study. Some patients did not undergo tumor evaluation because their disease was not well-controlled after afatinib initiation. Although AEs may be difficult to be recorded accurately due to the retrospective nature of the study, the overall $\mathrm{AE}$ frequency was comparable with the rates reported in previous clinical trials [79]. Moreover, $96.8 \%$ of the patients in these studies

Table 4 Treatment-related AEs

\begin{tabular}{|c|c|c|c|c|c|c|c|c|c|c|c|c|c|c|}
\hline \multirow[t]{2}{*}{ AEs } & \multicolumn{7}{|c|}{ Any grade } & \multicolumn{7}{|c|}{ Grade 3-4 } \\
\hline & $\begin{array}{l}\text { All } \\
(N=62)\end{array}$ & $\%$ & $\begin{array}{l}\text { Afatinib } 40 \\
\mathrm{mg}(N=39)\end{array}$ & $\%$ & $\begin{array}{l}\text { Afatinib } 30 \\
\mathrm{mg}(N=23)\end{array}$ & $\%$ & $\overline{p \text {-value }}$ & $\begin{array}{l}\text { All } \\
(N=62)\end{array}$ & $\%$ & $\begin{array}{l}\text { Afatinib } 40 \\
\mathrm{mg}(N=39)\end{array}$ & $\%$ & $\begin{array}{l}\text { Afatinib } 30 \\
\mathrm{mg}(N=23)\end{array}$ & $\%$ & $\overline{p \text {-value }}$ \\
\hline $\begin{array}{l}\text { Any adverse } \\
\text { effects }\end{array}$ & 60 & $96.8 \%$ & 39 & $100.0 \%$ & 21 & $91.3 \%$ & 0.061 & 14 & $22.6 \%$ & 12 & $30.8 \%$ & 2 & $8.7 \%$ & 0.045 \\
\hline Diarrhea & 54 & $87.1 \%$ & 36 & $92.3 \%$ & 18 & $78.3 \%$ & 0.111 & 7 & $11.3 \%$ & 6 & $15.4 \%$ & 1 & $4.3 \%$ & 0.185 \\
\hline Acneiform & 8 & $12.9 \%$ & 6 & $15.4 \%$ & 2 & $8.7 \%$ & 0.448 & 0 & $0.0 \%$ & 0 & $0.0 \%$ & 0 & $0.0 \%$ & - \\
\hline Paronychia & 28 & $45.2 \%$ & 20 & $51.3 \%$ & 8 & $34.8 \%$ & 0.207 & 6 & $9.7 \%$ & 5 & $12.8 \%$ & 1 & $4.3 \%$ & 0.276 \\
\hline Skin lesions & 39 & $62.9 \%$ & 28 & $71.8 \%$ & 11 & $47.8 \%$ & 0.059 & 3 & $4.8 \%$ & 3 & $7.7 \%$ & 0 & $0.0 \%$ & 0.173 \\
\hline Pruritus & 1 & $1.6 \%$ & 1 & $2.6 \%$ & 0 & $0.0 \%$ & 0.439 & 0 & $0.0 \%$ & 0 & $0.0 \%$ & 0 & $0.0 \%$ & - \\
\hline $\begin{array}{l}\text { Nausea and } \\
\text { vomiting }\end{array}$ & 5 & $8.1 \%$ & 3 & $7.7 \%$ & 2 & $8.7 \%$ & 0.889 & 0 & $0.0 \%$ & 0 & $0.0 \%$ & 0 & $0.0 \%$ & - \\
\hline Constipation & 3 & $4.8 \%$ & 3 & $7.7 \%$ & 0 & $0.0 \%$ & 0.173 & 0 & $0.0 \%$ & 0 & $0.0 \%$ & 0 & $0.0 \%$ & - \\
\hline Dry skin & 5 & $8.1 \%$ & 2 & $5.1 \%$ & 3 & $13.0 \%$ & 0.269 & 0 & $0.0 \%$ & 0 & $0.0 \%$ & 0 & $0.0 \%$ & - \\
\hline Mucositis & 24 & $38.7 \%$ & 18 & $46.2 \%$ & 6 & $26.1 \%$ & 0.117 & 4 & $6.5 \%$ & 4 & $10.3 \%$ & 0 & $0.0 \%$ & 0.112 \\
\hline $\begin{array}{l}\text { Hand foot } \\
\text { syndrome }\end{array}$ & 2 & $3.2 \%$ & 2 & $5.1 \%$ & 0 & $0.0 \%$ & 0.270 & 1 & $1.6 \%$ & 1 & $2.6 \%$ & 0 & $0.0 \%$ & 0.439 \\
\hline Eye & 2 & $3.2 \%$ & 2 & $5.1 \%$ & 0 & $0.0 \%$ & 0.270 & 0 & $0.0 \%$ & 0 & $0.0 \%$ & 0 & $0.0 \%$ & - \\
\hline Edema & 1 & $1.6 \%$ & 1 & $2.6 \%$ & 0 & $0.0 \%$ & 0.439 & 0 & $0.0 \%$ & 0 & $0.0 \%$ & 0 & $0.0 \%$ & - \\
\hline Onycholysis & 1 & $1.6 \%$ & 1 & $2.6 \%$ & 0 & $0.0 \%$ & 0.439 & 0 & $0.0 \%$ & 0 & $0.0 \%$ & 0 & $0.0 \%$ & - \\
\hline
\end{tabular}

$A E$ adverse event 
Wu et al. BMC Cancer $\quad$ (2021) 21:859

Page 12 of 14

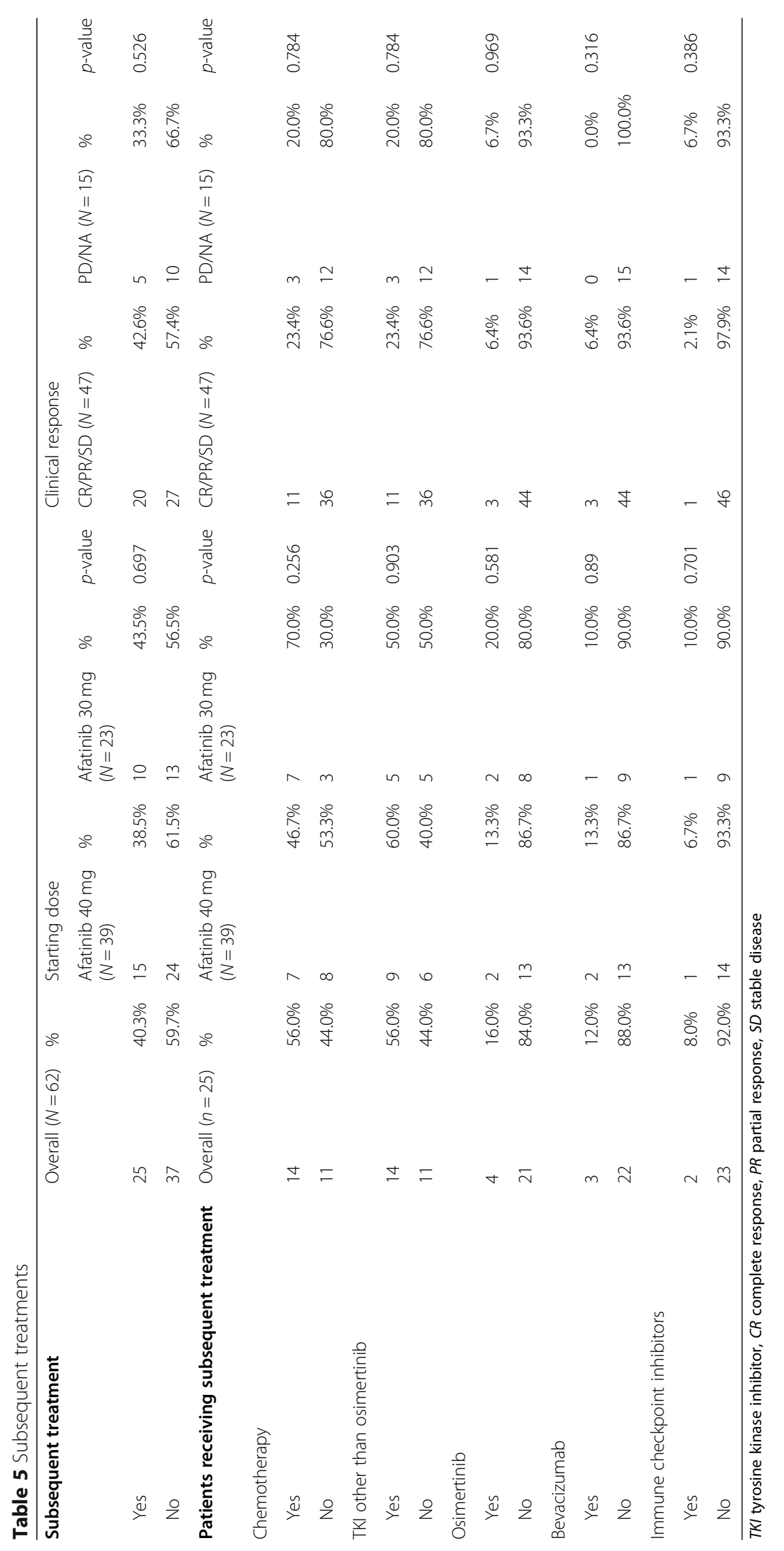


experienced various grades of $\mathrm{AE}$, indicating that the results of the current study are reliable.

In conclusion, we reported the real-world experience of afatinib when used as first-line treatment for EGFRm + NSCLC patients with poor PS. This study demonstrated that afatinib is feasible and effective for EGFRm+ NSCLC patients classified as poor PS, is generally well-tolerated, and has acceptable anti-tumor activity. This study provided evidence to support the use of afatinib to treat patients with poor PS. However, further studies with a larger cohort remain necessary to confirm our findings.

\section{Abbreviations}

AE: Adverse events; BMI: Body mass index; BSA: Body surface area; $\mathrm{Cl}$ : Confidence interval; CR: Complete response; DCR: Disease control rate; ECOG: Eastern Cooperative Oncology Group; EGFR: Epidermal growth factor receptor; EGFRm+: EGFR-mutation-positive; HER: Human epidermal growth factor receptor; HR: Hazard ratio; mOS: Median OS; mPFS: Median PFS; NA: Not assessed; NSCLC: Non-small-cell lung cancer; OS: Overall survival; PD: Progressive disease; PFS: Progression-free survival; PR: Partial response; PS: Performance status; SD: Stable disease; TTF: Time to treatment failure

\section{Acknowledgments}

This work was supported by Chang Gung Research Database. This work was supported by grants from Linkou Chang Gung Memorial Hospital. The editorial assistance was provided to the authors by Nova Journal Experts.

\section{Authors' contributions}

Conception and design of study: CEW, JWCC, CFC. Acquisition of data: CEW, JWCC, CFC. Analysis and interpretation of data: CEW, JWCC, CFC. Drafting the manuscript: CEE, JWCC, CFC, PCH. Revising the manuscript critically for important intellectual content: CEW, CYH, CTY, CHS, PCH. Data validation: CEW, CYH, CTY, CHSK. Supervision: CEW, JWCC. The author(s) read and approved the final manuscript.

\section{Funding}

This work was supported by grants from Linkou Chang Gung Memorial Hospital [CIRPG3H0061 2 and CORPG3J0151 2 to J.W-C.C.; CMRPG3J0971 $\sim$ 3, CRRPG3K0021 2, NMRPG3K6201 3, CMRPG3K0601 to C-E.W.]. The funding bodies had no roles in the design, conduct, analysis or interpretation of the study and in writing the manuscript.

\section{Availability of data and materials}

The data supporting the findings of this study are available from Cancer Registry databank at CGMH and Chang Gung Research Database [20], but restrictions apply to their availability. These data were used under the approval of Institutional Review Board at CGMH for the current study, and so are not publicly available. The de-linked, and anonymized datasets used and/ or analyzed during the current study are available from the corresponding author on reasonable request.

\section{Declarations}

Ethics approval and consent to participate

Not applicable.

\section{Consent for publication}

Not applicable.

\section{Competing interests}

The authors declare that they have no competing interests.

\section{Author details}

${ }^{1}$ Department of Internal Medicine, Division of Hematology-Oncology, Chang Gung Memorial Hospital at Linkou, Chang Gung University College of Medicine, No. 5, Fu-Hsing Street, Kwei-Shan District, Taoyuan City 333, Taiwan. ${ }^{2}$ Department of Thoracic Medicine, Division of Thoracic Oncology,
Chang Gung Memorial Hospital at Linkou, Chang Gung University College of Medicine, No. 5, Fu-Hsing Street, Kwei-Shan District, Taoyuan City 333, Taiwan.

Received: 27 October 2020 Accepted: 29 June 2021

Published online: 27 July 2021

\section{References}

1. Lynch TJ, Bell DW, Sordella R, Gurubhagavatula S, Okimoto RA, Brannigan BW, et al. Activating mutations in the epidermal growth factor receptor underlying responsiveness of non-small-cell lung cancer to gefitinib. N Engl J Med. 2004;350(21):2129-39. https://doi.org/10.1056/NEJMoa040938.

2. Mok TS, Wu YL, Thongprasert S, Yang CH, Chu DT, Saijo N, et al. Gefitinib or carboplatin-paclitaxel in pulmonary adenocarcinoma. N Engl J Med. 2009; 361(10):947-57. https://doi.org/10.1056/NEJMoa0810699.

3. Maemondo M, Inoue A, Kobayashi K, Sugawara S, Oizumi S, Isobe H, et al. Gefitinib or chemotherapy for non-small-cell lung cancer with mutated EGFR. N Engl J Med. 2010;362(25):2380-8. https://doi.org/10.1056/NEJMoa 0909530.

4. Zhou C, Wu YL, Chen G, Feng J, Liu XQ, Wang C, et al. Erlotinib versus chemotherapy as first-line treatment for patients with advanced EGFR mutation-positive non-small-cell lung cancer (OPTIMAL, CTONG-0802): a multicentre, open-label, randomised, phase 3 study. Lancet Oncol. 2011; 12(8):735-42. https://doi.org/10.1016/S1470-2045(11)70184-X.

5. Rosell R, Carcereny E, Gervais R, Vergnenegre A, Massuti B, Felip E, et al. Erlotinib versus standard chemotherapy as first-line treatment for European patients with advanced EGFR mutation-positive non-small-cell lung cancer (EURTAC): a multicentre, open-label, randomised phase 3 trial. Lancet Oncol. 2012;13(3):239-46. https://doi.org/10.1016/S1470-2045(11)70393-X.

6. Mitsudomi T, Morita S, Yatabe Y, Negoro S, Okamoto I, Tsurutani J, et al. Gefitinib versus cisplatin plus docetaxel in patients with non-small-cell lung cancer harbouring mutations of the epidermal growth factor receptor (WJTOG3405): an open label, randomised phase 3 trial. Lancet Oncol. 2010; 11(2):121-8. https://doi.org/10.1016/S1470-2045(09)70364-X.

7. Sequist LV, Yang JC, Yamamoto N, O'Byrne K, Hirsh V, Mok T, et al. Phase III study of afatinib or cisplatin plus pemetrexed in patients with metastatic lung adenocarcinoma with EGFR mutations. J Clin Oncol. 2013;31(27):332734. https://doi.org/10.1200/JCO.2012.44.2806.

8. Wu YL, Zhou C, Hu CP, Feng J, Lu S, Huang Y, et al. Afatinib versus cisplatin plus gemcitabine for first-line treatment of Asian patients with advanced non-small-cell lung cancer harbouring EGFR mutations (LUX-lung 6): an open-label, randomised phase 3 trial. Lancet Oncol. 2014;15(2):213-22. https://doi.org/10.1016/S1470-2045(13)70604-1.

9. Park K, Tan EH, O'Byrne K, Zhang L, Boyer M, Mok T, et al. Afatinib versus gefitinib as first-line treatment of patients with EGFR mutation-positive nonsmall-cell lung cancer (LUX-lung 7): a phase 2B, open-label, randomised controlled trial. Lancet Oncol. 2016;17(5):577-89. https://doi.org/10.1016/S14 70-2045(16)30033-X.

10. Soria JC, Ohe Y, Vansteenkiste J, Reungwetwattana T, Chewaskulyong B, Lee $\mathrm{KH}$, et al. Osimertinib in untreated EGFR-mutated advanced non-small-cell lung Cancer. New Engl J Med. 2018;378(2):113-25. https://doi.org/10.1056/ NEJMoa1713137.

11. Ramalingam SS, Vansteenkiste J, Planchard D, Cho BC, Gray JE, Ohe Y, et al. Overall survival with Osimertinib in untreated, EGFR-mutated advanced NSCLC. New Engl J Med. 2020;382(1):41-50. https://doi.org/10.1056/ NEJMoa1913662.

12. Tu CY, Chen CM, Liao WC, Wu BR, Chen CY, Chen WC, et al. Comparison of the effects of the three major tyrosine kinase inhibitors as first-line therapy for non-small-cell lung cancer harboring epidermal growth factor receptor mutations. Oncotarget. 2018;9:24237-47. https://doi.org/10.18632/oncota rget.24386.

13. Lin YT, Chen JS, Liao WY, Ho CC, Hsu CL, Yang CY, et al. Clinical outcomes and secondary epidermal growth factor receptor (EGFR) T790M mutation among first-line gefitinib, erlotinib and afatinib-treated non-small cell lung cancer patients with activating EGFR mutations. Int J Cancer. 2019;144(11): 2887-96. https://doi.org/10.1002/ijc.32025.

14. Kuan FC, Li SH, Wang CL, Lin MH, Tsai YH, Yang CT. Analysis of progressionfree survival of first-line tyrosine kinase inhibitors in patients with non-small cell lung cancer harboring leu858Arg or exon 19 deletions. Oncotarget. 2017:8:1343-53. https://doi.org/10.18632/oncotarget.13815. 
15. Shen YC, Tseng GC, Tu CY, Chen WC, Liao WC, Chen WC, et al. Comparing the effects of afatinib with gefitinib or erlotinib in patients with advancedstage lung adenocarcinoma harboring non-classical epidermal growth factor receptor mutations. Lung Cancer. 2017;110:56-62. https://doi.org/10.1 016/j.lungcan.2017.06.007.

16. Park K, Lim DWT, Okamoto I, Yang JCH. First-line afatinib for the treatment of EGFR mutation-positive non-small-cell lung cancer in the 'real-world' clinical setting. Ther Adv Med Oncol. 2019;11. https://doi.org/10.1177/1 758835919836374.

17. Ito K, Murotani K, Kubo A, Kunii E, Taniguchi H, Shindo J, et al. Comparative analysis of overall survival using propensity score between first- and second-generation EGFR-TKl: real world data of 1354 patients with EGFR mutant NSCLC. Ann Oncol. 2018;29:viii526-7. https://doi.org/10.1093/a nnonc/mdy292.077.

18. Su PL, Wu YL, Chang WY, Ho CL, Tseng YL, Lai WW, et al. Preventing and treating brain metastases with three first-line EGFR-tyrosine kinase inhibitors in patients with EGFR mutation-positive advanced non-small cell lung cancer. Ther Adv Med Oncol. 2018;10:1758835918797589. https://doi.org/1 $0.1177 / 1758835918797589$

19. Kim Y, Lee SH, Ahn JS, Ahn MJ, Park K, Sun JM. Efficacy and safety of Afatinib for EGFR-mutant non-small cell lung Cancer, compared with Gefitinib or Erlotinib. Cancer Res Treat. 2019;51(2):502-9. https://doi.org/1 $0.4143 /$ crt.2018.117.

20. Tsai MS, Lin MH, Lee CP, Yang YH, Chen WC, Chang GH, et al. Chang gung research database: a multi-institutional database consisting of original medical records. Biom J. 2017;40(5):263-9. https://doi.org/10.1016/j.bj.2017. 08.002 .

21. Hsieh YY, Fang WT, Lo YW, Chen YH, Chien LN. Comparing the effectiveness of different EGFR-TKIs in patients with EGFR mutant non-small-cell lung cancer: a retrospective cohort study in Taiwan. Int J Cancer. 2019;147(4): 1107-16. https://doi.org/10.1002/ijc.32841.

22. He YY, Wang Y, Boyle T, Ren SX, Chan D, Rivard C, et al. Hepatic Metastases is Associated with Poor Efficacy of Erlotinib as $2 n d / 3 r d$ Line Therapy in Patients with Lung Adenocarcinoma. Med Sci Monit. 2016;22:276-83. https://doi.org/10.12659/Msm.896607.

23. Chang YP, Chen YM, Lai CH, Lin CY, Fang WF, Huang CH, et al. The impact of de novo liver metastasis on clinical outcome in patients with advanced non-small-cell lung cancer. PLoS One. 2017;12. https://doi.org/10.1371/ journal.pone. 0178676 .

24. Ho GF, Chai CS, Alip A, Wahid MIA, Abdullah MM, Foo YC, et al. Real-world experience of first-line afatinib in patients with EGFR-mutant advanced NSCLC: a multicenter observational study. BMC Cancer. 2019;19. https://doi. org/10.1186/s12885-019-6107-1.

25. Yang CJ, Tsai MJ, Hung JY, Lee MH, Tsai YM, Tsai YC, et al. The clinical efficacy of Afatinib $30 \mathrm{mg}$ daily as starting dose may not be inferior to Afatinib $40 \mathrm{mg}$ daily in patients with stage IV lung Adenocarcinoma harboring exon 19 or exon 21 mutations. BMC Pharmacol Toxicol. 2017;18. https://doi.org/10.1186/s40360-017-0190-1.

26. Halmos B, Tan EH, Lee MK, Foucher P, Hsia TC, Hochmair MJ. Real-world dose adjustment study of first-line afatinib in pts with EGFR mutationpositive (EGFRm plus) advanced NSCLC. J Clin Oncol. 2018;36. https://doi. org/10.1200/JCO.2018.36.15_suppl.e21060.

\section{Publisher's Note}

Springer Nature remains neutral with regard to jurisdictional claims in published maps and institutional affiliations.

Ready to submit your research? Choose BMC and benefit from:

- fast, convenient online submission

- thorough peer review by experienced researchers in your field

- rapid publication on acceptance

- support for research data, including large and complex data types

- gold Open Access which fosters wider collaboration and increased citations

- maximum visibility for your research: over $100 \mathrm{M}$ website views per year

At BMC, research is always in progress.

Learn more biomedcentral.com/submissions 